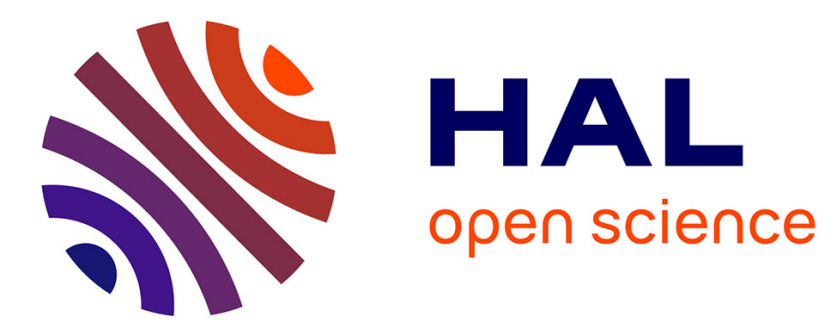

\title{
Changes in soil organic matter driven by shifts in co-dominant plant species in a grassland
}

Reza Erfanzadeh, Behnam Bahrami, Javad Motamedi, Julien Petillon

\section{To cite this version:}

Reza Erfanzadeh, Behnam Bahrami, Javad Motamedi, Julien Petillon. Changes in soil organic matter driven by shifts in co-dominant plant species in a grassland. Geoderma, 2014, 213, pp.74-78. 10.1016/j.geoderma.2013.07.027 . hal-00875310

HAL Id: hal-00875310

https://hal-univ-rennes1.archives-ouvertes.fr/hal-00875310

Submitted on 21 Oct 2013

HAL is a multi-disciplinary open access archive for the deposit and dissemination of scientific research documents, whether they are published or not. The documents may come from teaching and research institutions in France or abroad, or from public or private research centers.
L'archive ouverte pluridisciplinaire HAL, est destinée au dépôt et à la diffusion de documents scientifiques de niveau recherche, publiés ou non, émanant des établissements d'enseignement et de recherche français ou étrangers, des laboratoires publics ou privés. 


\title{
Changes in soil organic matter driven by shifts in co-dominant
}

\section{plant species in a grassland}

\author{
R. Erfanzadeh ${ }^{1}$, B. Bahrami ${ }^{1}$, J. Motamedi $^{2}$, Julien Pétillon ${ }^{3}$
}

1. Rangeland Department, Faculty of Natural Resources, Tarbiat Modares University, Iran;

2. Rangeland Department, Faculty of Natural Resources and Agriculture, Urmia University, Iran.

3. URU 420 - Université de Rennes 1, UMR 7204 - Muséum National d'Histoire National, 263 Avenue du Général Leclerc, CS 74205, 35042 Rennes Cedex, France. $\underline{\text { Julien.petillon@univ-rennes1.fr }}$

*Corresponding Author: $\quad$ Rezaerfanzadeh@modares.ac.ir; $\quad$ Tel. +989373181169; Fax $+98122625349$ 


\begin{abstract}
Globally, grassland soils, if managed properly, are important for the sake of carbon sequestration. The quality and quantity of soil organic carbon is probably influenced by vegetation traits such as composition and plant species. We determined the influence of vegetation composition and co-dominant species on soil organic carbon in two Prangus uloptera stands. The stands situated at close proximity were identified in a Prangos uloptera community in north-western Iran. Both stands shared similar dominant plant species with the same physiographical and climatological characteristics, but differed in their co-dominant plant species. To compare soil organic matter (SOM) parameters, soil samples from each stand were collected from depths of $0-15 \mathrm{~cm}$ and $15-30 \mathrm{~cm}$. The results showed that $\mathrm{SOM}$ had spatial variation which was probably affected by the plant species. The highest values of total C, Total N, POM-C, POM-N, microaggregates, $\mathrm{C}$ in macroaggregates and $\mathrm{C}$ in microaggregates in the upper soil layer occurred in the stand with the highest cover of Astragalus microcephalus and Acanthophyllum microcephalum. It is suggested that, in conservation projects based on higher carbon sequestration, the plant species with more incorporation of carbon content into soil should be identified and used more widely. .
\end{abstract}

Key words: Carbon sequestration, Plant species, Soil organic carbon, Vegetation type, Prangus uloptera stands. 


\section{Introduction}

Soil organic matter (SOM), a key component of soil-plant ecosystems, is closely associated with soil features and processes (Chen et al., 2004). SOM can be divided into labile, slow and recalcitrant organic matter according to its turnover rate (Six et al., 2002). Labile SOM, with a shorter turnover time, can respond sensitively to changes in vegetation compared to total SOM in world ecosystems (Laik et al., 2009). However, previous studies showed that vegetation composition is likely to influence some soil parameters. For instance, Wardle and Van der Putten (2002) and Wardle and Zackrisson (2005) claimed that plant species could affect the number and activity of soil biota. In addition, the quality and quantity of SOM might depend on the nature and composition of the plant community. The quality and quantity of SOC (soil organic carbon) are also affected by vegetation traits such as composition and plant species. Studies investigating the effects of environmental conditions on soil ecosystems have mainly concerned forest ecosystems (e.g. Ashagrie et al., 2007; Christenson et al., 2009; Wang and Wang, 2011), shrubland (e.g. An et al., 2010), cultivated stands ( e.g. GartziaBengoetxea et al., 2009), crop production (e.g., Haynes, 1999; Huang et al., 2010; Beedy et al., 2010), land use (e.g. Bettina et al., 2005; Leifeld and Kögel, 2005) and overgrazed pastures (Fallahzade and Hajabbasi, 2011), but none of these studies focused on the effect of co-dominant species on total and labile SOM. In addition, the physical location (e.g. aggregates) of the organic matter in soil and how this will be influenced by vegetation composition in a single habitat is not well understood.

Rangeland ecosystems are very diverse (i.e. grassland, shrubland, savannas, hot and cold deserts, and tundra), and play an important role in storing carbon both above and below ground. In 1993, carbon (C) stored in the world's rangeland soils was estimated to be 591.6 Gt, or $44 \%$ of the world's total soil carbon (Solomon et al., 1993). Grassland soils are known for their high levels of organic matter and high structural stability (van Veen and Paul, 1981), 
although they vary among habitats and vegetation types (Solomon et al., 1993). Preindustrial levels of soil $\mathrm{C}$ (to depths of $20 \mathrm{~cm}$ ) in grassland alone have been estimated to be approximately 96 Gt (Ojima et al., 1993b). Soil C stocks for these grasslands are around 81164 Gt, based on land cover estimates of Bailey (1989). As a result, grassland soils, if managed properly, are important for carbon sequestration and a small increase in SOC may decrease the atmospheric $\mathrm{CO}_{2}$ concentration and alter the global climate positively (Bu et al., 2012).

The objective of this study was to determine the influence of vegetation composition and especially that of co-dominant species, on total C, total N, particulate organic matter C (POMC), particulate organic matter N (POM-N), macro- and micro aggregate distribution and Cassociated with macro- and micro-aggregates in a Prangus uloptera-dominated Iranian grassland.

\section{Materials and Methods}

\subsection{Description of the study area}

This study was carried out in north-western Iran, within the grassland ecosystem of the Khanghah watershed, extending over about 2000 ha between latitudes $37^{\circ} 46^{\prime} 18^{\prime \prime} \mathrm{N}$ and $37^{\circ} 50^{\prime} 42^{\prime \prime N}$ and longitudes $44^{\circ} 57^{\prime} 04^{\prime \prime} \mathrm{E}$ and $45^{\circ} 00^{\prime} 32^{\prime \prime} \mathrm{E}$. Mean annual precipitation, temperature and altitude are $393.9 \mathrm{~mm}, 9.87^{\circ} \mathrm{C}$ and ca. $1725 \mathrm{~m}$ a.s.l., respectively. Prangos uloptera DC plant communities were selected for the study. The Prangus genus is widespread in north-western Iran and consists of 15 species. Prangos uloptera is one of the most important species and has medicinal, industrial and foraging uses. The community was distinguished according to the dominant plant species (Heady and Child, 1994) (here Prangos uloptera), and two adjacent stands were identified in the community. Both stands were classified as "good" for rangeland condition and "stable" for rangeland trend according to 
Holechek's (1989) method (Motamedi et al. 2009). In both stands, the percentage cover of dominant plant species and other physiographical and climatological characteristics were similar and the stands mostly differed in the co-dominant plant species. In the first stand (hereafter coded Prangos ulopteral), the co-dominant plant species were Pterpyrum aucheri and Artemisia aucheri, and in the second stand (hereafter coded Prangos uloptera2), the codominant plant species were Astragalus microcephalus, Acanthophyllum microcephalum and Poa bulbosa (Table 1).

\subsection{Soil sampling}

Soil samples from each stand were collected from depths of 0 to $15 \mathrm{~cm}$ and 15 to $30 \mathrm{~cm}$ during spring 2011. Two key areas were selected within each stand to avoid pseudoreplication, yet the stands were close to each to other to limit co-varying factors other than codominant species (see for instance Oksanen, 2001). This area was considered as the representative of the entire habitat in that location (Heady and Child, 1994). In each key area, six transects were established: three parallel and three perpendicular to the slope. Three $4 \mathrm{~m} \times 4 \mathrm{~m}$ quadrats were established at the beginning, the middle and the end of each transect. In each quadrat, 10 soil cores were collected at random, to a depth of $30 \mathrm{~cm}$, with a $5 \mathrm{~cm}$ diameter auger (each core was divided into two sub-cores (0-15 and 15-30cm) and sub-cores were then pooled per depth for each quadrat. All of the soil samples were immediately transferred to a cooled, insulated container for transport to the laboratory and were stored at $4^{\circ} \mathrm{C}$ until they were processed. The samples were sieved, the roots and coarse gravel $(>5 \mathrm{~mm})$ were removed by sieving, and the $<5 \mathrm{~mm}$ soil was used to examine the effects of vegetation composition on soil parameters.

\subsection{Soil and data analysis}


Organic C was determined by the Loss of Ignition method (Lal et al., 2001) and total soil N by wet oxidation using the Kjeldahl method (Zagal et al., 2009). The POM was determined by physical fractionation (Cambardella and Elliot, 1992). Twenty-five grams of air-dried soil samples were dispersed with $100 \mathrm{ml}$ of $5 \mathrm{~g} / \mathrm{l}$ of sodium hexametaphosphate. The soil solution mixture was shaken for $1 \mathrm{~h}$ at high speed $(=500 \mathrm{rpm})$ on an end-to-end shaker and poured over a $0.053 \mathrm{~mm}$ sieve with several deionized water rinses. The soil remaining on the sieve was back washed into a pre-weighed aluminium dish and dried at $60^{\circ} \mathrm{C}$ for $24 \mathrm{~h}$, then ground and analyzed for C and N (see also Handayani et al., 2009).

Aggregate size distribution was determined using wet sieving with screen diameters of 0.25 and $0.50 \mathrm{~mm}$. The range of micro-aggregates and macro-aggregates was between 0.053 to $0.25 \mathrm{~mm}$ and 0.25 to $0.50 \mathrm{~mm}$, respectively. Soils samples were submersed in water on the largest screen for 5 min before sieving commenced. Soils were sieved under water by gently moving the sieve $3 \mathrm{~cm}$ vertically through water contained in a shallow pan, 50 times over period of 2 min. Material remaining on the sieve was transferred to an aluminium container and dried at $60^{\circ} \mathrm{C}$ in a forced-air oven then weighed and measured for $\mathrm{C}$ (Elliot and Cambardella, 1991).

Soil parameters of the two stands were compared using t-tests at the 5\% significance level.

\section{Results}

\subsection{Total organic carbon and nitrogen content in soils}

Total $\mathrm{C}$ in the upper layer $(0-15 \mathrm{~cm}$ soil depth) was significantly higher in the Prangos uloptera2 stand compared to Prangos ulopteral $(9.5 \mathrm{~g} / \mathrm{kg}$ vs. $3.6 \mathrm{~g} / \mathrm{kg}$, respectively; $\mathrm{t}=-25.34$, $\mathrm{p}<0.01$ ) (Fig. 1A). At the 15 to $30 \mathrm{~cm}$ soil depth, the difference between the two stands was significant with $6.4 \mathrm{~g} / \mathrm{kg}$ and $3.2 \mathrm{~g} / \mathrm{kg}$ in Prangos uloptera 2 and Prangos ulopteral, respectively $(\mathrm{t}=-16.62, \mathrm{p}<0.01)$. 
Total $\mathrm{N}$ content in the upper layer increased from $0.4 \mathrm{~g} / \mathrm{kg}$ to $1.2 \mathrm{~g} / \mathrm{kg}$ and in lower layer from $0.4 \mathrm{~g} / \mathrm{kg}$ to $1.0 \mathrm{~g} / \mathrm{kg}$ in Prangos ulopteral and Prangos uloptera2, respectively $(\mathrm{t}=-21.65, \mathrm{p}<0.01$; $\mathrm{t}=-19.38, \mathrm{p}<0.01)($ Fig. 2A).

\subsection{Labile SOM fractions}

Soil POM-C and also POM-N were generally higher in the Prangos uloptera2 (Fig. 1B and Fig. 2B) stand compared to the other treatment. POM-C contents in Prangos ulopteral and Prangos uloptera2 were $0.3 \mathrm{~g} / \mathrm{kg}$ and $2.9 \mathrm{~g} / \mathrm{kg}$ in the upper soil layer, respectively $(\mathrm{t}=-88.33, \mathrm{p}<0.01)$. POM-C contents in Prangos ulopteral and Prangos uloptera 2 were $0.7 \mathrm{~g} / \mathrm{kg}$ and $1.5 \mathrm{~g} / \mathrm{kg}$ in the deeper soil layer, respectively $(\mathrm{t}=-23.82, \mathrm{p}<0.01)$. POM-N contents in both depths of the Prangos uloptera 2 stand were significantly higher than the Prangos ulopteral stand $(0.4 \mathrm{~g} / \mathrm{kg}$ and $0.2 \mathrm{~g} / \mathrm{kg}$ vs. $0.1 \mathrm{~g} / \mathrm{kg}$ and $0.1 \mathrm{~g} / \mathrm{kg})(\mathrm{t}=-26.84, \mathrm{p}<0.01 ; \mathrm{t}=-2.86, \mathrm{p}<0.01)($ Fig. $2 \mathrm{~B})$.

\subsection{Aggregate distribution and carbon associated with aggregate size classes}

There was a significantly smaller proportion of soil in macro-aggregates in Prangos uloptera2 compared to Prangos ulopteral in both depths (upper layer: $\mathrm{t}=21.68, \mathrm{p}<0.01$; lower layer: $\mathrm{t}=$ 35/29, p<0.01) (Fig. 3A). Conversely, there was a significantly smaller proportion of soil in micro-aggregates in Prangos ulopteral compared to Prangos uloptera2 in both depths of the upper layer $(\mathrm{t}=-21.68, \mathrm{p}<0.01$; lower layer: $\mathrm{t}=-28 / 48, \mathrm{p}<0.01)($ Fig. $3 \mathrm{~B})$.

Carbon content was significantly greater for each aggregate in Prangos uloptera2 than Prangos ulopteral in both depths (Fig. 4A and 4B). The greatest significant difference $(\mathrm{t}=-14.63$, $\mathrm{P}<0.01)$ in $\mathrm{C}$ content between Prangos ulopteral and Prangos uloptera 2 was in the macroaggregates at the $0-15 \mathrm{~cm}$ soil depth $(0.26$ to $1.13 \mathrm{~g} / \mathrm{kg})$ compared to the micro-aggregates $(0.86$ to $1.54 \mathrm{~g} / \mathrm{kg})(\mathrm{t}=-18.80, \mathrm{p}<0.01)($ Fig. $4 \mathrm{~A}$ and $4 \mathrm{~B})$. 


\section{Discussion}

Results of this study showed that the total nitrogen, organic carbon and $\mathrm{C}$ associated with micro- and macro-aggregates were significantly higher in the Prangos uloptera2 than the Prangos ulopteral community. We suggest that the two co-dominant plant species, with the higher canopy cover in Prangos uloptera2 compared to the other stand, are responsible for this difference. The first species is Acanthophyllum microcephalum with a mean percentage cover of $17 \%$ in Prangos uloptera 2 compared with $4 \%$ in Prangos ulopteral. This species is a relatively large shrubby plant with high production in the Iranian range lands (Arzani et al., 2005). Nutrient accumulation as fertile islands beneath shrubs in grassland is common and provides opportunities for carbon and nitrogen sequestration in arid and semi-arid regions (e.g. Jackson et al., 2002). Mcclaran et al. (2008) showed that the SOM and total nitrogen accumulation was $80-750 \%$ greater in the beneath Prosopis velutina than in the open grassland. The second species with a high proportion of canopy cover in Prangos uloptera2 was a leguminous species, Astragalus microcephalus which is a deciduous shrub growing to $0.5 \mathrm{~m}$. It produces woody stems which tend to die back almost to the base each winter. This species has a symbiotic relationship with certain soil bacteria, which form nodules on the roots and fix atmospheric nitrogen (Huxley and Griffiths, 1992). Increasing $\mathrm{N}$ to the soil via $\mathrm{N}_{2}$ fixation and plant organic inputs by this species may increase total $\mathrm{N}$ and $\mathrm{C}$ in the soils of Prangos uloptera2. Moreover, the tiny dense shallow roots of Poa bulbosa (Barnhart, 1895) may increase organic carbon in the Prangos uloptera2 community. Previous studies also showed that soil carbon additions are governed by the volume of fibrous roots per unit of soil and the rate of growth of gramineae. The greater the number of active green leaves and active plant roots, the more carbon is captured from the air, and thus translocated through the plant and exuded into the soil (Jones, 2006; Kadović, 2012). 
Soil $\mathrm{C}$ and $\mathrm{N}$ contents play a crucial role in sustaining soil and environmental quality ( $\mathrm{Su}$, 2007). In addition, knowledge of the effects of vegetation type and plant composition on SOM status is essential in natural habitats when considering conservation strategies based on higher carbon sequestration in these habitats. In this study, SOM had spatial variation in natural habitats, driven by the plant composition, and mainly by the difference in co-dominant species. Our findings are similar to those obtained by a few other studies. Monokrousos et al. (2004) showed that soil samples collected from sites with dimorphic species share common soil properties, whereas sites with different evergreen species showed distinct soil properties for each species. Roukos et al. (2011) found that SOM is significantly affected by the plant community and $\mathrm{Bu}$ et al. (2012) observed that the $\mathrm{C} / \mathrm{N}$ ratio in density fractions were higher in coniferous areas than in alpine meadows. Oueslati et al. (2013) found that organic carbon was significantly affected by the plant species in the ground vegetation. Contrary to our results, Mendham et al. (2004) and Peichl et al. (2012) reported that changing the plant community and species by the afforestation of grassland had no significant impact on total soil $\mathrm{C}$ and $\mathrm{N}$ stocks.

However, studies on the effect of vegetation on SOM are scarce in natural habitats. In managed lands and cultivated areas, practices may also have wide-ranging impacts on soil $\mathrm{C}$ and N (Marcos et al., 2006; Luan et al., 2010; Fallahzade and Hajabbasi, 2010; Beedy et al., 2010). SOM may also be affected by climate, soil texture, nutrient statuses and time since the land management was initiated (Franzluebbers and Arshad, 1997; De Koning et al, 2003).

Labile fractions of SOM have already been suggested as important indicators of impacts on soil resulting from management practices (e.g. Handayani, 2004; Sequeira et al., 2011). This study also revealed the sensitivity of labile fractions of soil to natural vegetation changes. The differences in vegetation between Prangos ulopteral and Prangos uloptera2 increased POM-C and POM-N, $89.6 \%$ and $75.0 \%$ in topsoil (0-15cm depth), respectively. While, total $\mathrm{C}$ and $\mathrm{N}$ in 
the upper layer were increased $62.1 \%$ and $66.6 \%$, respectively by vegetation differences between Prangos ulopteral and Prangos uloptera2. The ranges of quantities of POM-C and POM$\mathrm{N}$ in the study area were 0.3 to $2.9 \mathrm{~g} / \mathrm{kg}$ and 0.1 to $0.4 \mathrm{~g} / \mathrm{kg}$, respectively. These values are in the range reported by Gupta et al., (1994) (POM-N: 0.13 to $0.29 \mathrm{~g} / \mathrm{kg}$ ) and Ordraogo et al., (2006) (POM-N: 0.11 to $0.27 \mathrm{~g} / \mathrm{kg}$ ) but lower than those observed by Handayani et al. (2009) (POM-C: 1.92 to $4.02 \mathrm{~g} / \mathrm{kg}$ and POM-N: 0.28 to $0.96 \mathrm{~g} / \mathrm{kg}$ ). Generally, the composition of POM consists mainly of root fragments (Cambardella and Elliot, 1992). Thus, significantly different levels of POM-C and POM-N between the two stands in this research would suggest differences in root biomass. It can be concluded that the leguminous species (Astragalus microcephalus) in Prangos uloptera2 probably promotes more decomposition and root regeneration due to additional $\mathrm{N}$, which may increase root contributions to $\mathrm{POM}$ (see also Tisdall, 1991, Braakhekke et al. 2013).

Here, the significant difference in macro-aggregates and micro-aggregates between the two stands may be due to the effect of the dense micro-roots of the leguminosae (Astragalus microcephalus) and the gramineae (Poa bulbosa) in Prangos uloptera2. Poaceae generally have a system of extensive tiny roots (Barnhart, 1895) that enfolds the soil ingredients like a trap and increases permanent aggregates in water. Prangos uloptera2 probably had fewer strong roots than Prangos ulopteral, thus decreasing the number of macro-aggregates. In accordance with our results, Liao et al. (2006) showed that, compared to herbaceous species (e.g. Eragrostis sp.), a woody species (Prosopis glandulosa) increased the relative proportions of the free light fraction and macro-aggregates and decreased the micro-aggregate size fraction. The reduction of macro-aggregates in soils under human activity has already been documented by previous works in which long-term cultivation has decreased the length and mass of fine roots and SOM, resulting in a reduction of macro-aggregates (Tisdall and Oades, 1980). 


\section{Conclusion}

This study reveals that changes in the co-dominance of plant species can have significant adverse effects on the proportion of SOC in natural grasslands. In conservation projects based on higher carbon sequestration, the manager should consequently identify the plant species which can absorb and add carbon into soil at a higher rate and try to improve their spatial extent.

\section{Acknowledgements}

We would like to acknowledge the Iranian University of Tarbiat Modares for technical and financial support. We thank Dr Y. Kouch for his valuable comments on an earlier draft. We also thank Aldyth Nys for the English revision.

\section{References}

Arzani, H., Adani, S.M., Bashari, H., Azimi, M., Bagheri, H., Akbarzadeh, M., Kaboli, S.H., 2007. Assessment of vegetation covers and yield variation in rangelands of Qom province (2000-2005). Iranian J. Range and Des. Res. 13, 296-313.

An, S., Mentler, A., Mayer, H., Blum, W. E. H., 2010. Soil aggregation, aggregate stability, organic carbon and nitrogen in different soil aggregate fractions under forest and shrub vegetation on the Loess Plateau, China. Catena. 81, 226-233.

Ashagrie, Y., Zech, W., Guggenberger, G., Mamo, T., 2007. Soil aggregation, and total and particulate organic matter following conversion of native forests to continuous cultivation in Ethiopia. Soil Till. Res. 94, 101-108.

Bailey, R. G., 1989. Explanatory supplement to ecoregions map of the continents. Environ. Conserv. 16, 307-309. 
Bardgett, R. D., Bowman, W. D., Kaufmann, R., Schmidt, S. K., 2005. A temporal approach to linking aboveground and belowground ecology. Trends Ecol. Evol. 20, 634641.

Barnhart, J. H., 1895. Poaceae. Bulletin of the Torrey Botanical Club 22, 7.

Beedy, T. L., Snapp, S. S., Akinnifesi, F. K., Sileshi, G. W., 2010. Impact of Gliricidia sepium intercropping on soil organic matter fractions in a maize-based cropping system. Agr. Ecosys. Environ. 138, 139-146.

Bettina, J., Yamashita, T., Ludwig, B., Flessa, H., 2005. Storage of organic carbon in aggregate and density fractions of silt soils under different types of land use. Geoderma. $128,63-79$.

Braakhekke, M. C., Wutzler T., Beer C., Kattge J., Schrumpf M., Ahrens B., Schöning I., Hoosbeek, M.R., Kruijt B., Kabat P., Reichstein M., 2013. Modeling the vertical soil organic matter profile using Bayesian parameter estimation. Biogeosciences. 10, 399-420.

Bu, X., Ruan, H., Wang, L., Ma, W., Ding, J., Yu, X., 2012. Soil organic matter in density fractions as related to vegetation changes along an altitude gradient in the Wuyi Mountains, southeastern China. Appl. Soil Ecol. 52, 42-47.

Cambardella, C. A., Elliott, E. T., 1992. Particulate soil organic matter Changes across a grassland cultivation sequence. Soil Sci. Soc. Am. J. 56, 777-783.

Chen, C. R., Xu Z. H., Mathers, N. J., 2004. Soil carbon pools in adjacent natural and plantation forests of subtropical Australia. Soil Sci. Soc. Am. J. 68, 282-291.

Christenson, L. M., Lovett, G. M., Weathers, K. C., Arthur, M. A., 2009. The influence of tree species, nitrogen fertilization, and soil $\mathrm{C}$ t o $\mathrm{N}$ ratio on gross soil nitrogen transformations. Soil Sci. Soc. Am. J . 73, 638-646. 
De Koning, J. H. J., Vedlkamp, E., Ulloa, M. L., 2003. Quantification of carbon sequestration in soils following pasture to forest conversion in Northwest Ecuador, Global Biogeochemistry. 17, 1098-1110.

Elliot, E. T., Cambardella, C. A., 1991. Physical separation of organic matter. Agr. Ecosys. Environ. 34, 407-419.

Fallahzade, J., Hajabbasi, M. A., 2010. The effects of irrigation and cultivation on the quality of desert soil in central Iran. Land Degrad. Dev. 23, 53-61.

Fallahzade, J., Hajabbasi, M. A., 2011. Soil organic matter status changes with cultivation of overgrazed pastures in semi-dry West central Iran. Int. J. Soil Sci. 6, 114-123.

Franzluebbers, A. J., Arshad, M. A., 1997. Soil microbial biomass and mineralizable carbon of water-stable aggregates, Am. J. Soil Sci. 61, 1090-1097.

Gartzia-Bengoetxea, N., Gonzalez-Arias, A., Merino, A., Martinez de Arano, I., 2009. Soil organic matter in soil physical fractions in adjacent semi-natural and cultivated stands in temperate Atlantic forests. Soil Biol. Biochem. 41, 1674-1683.

Handayani, I. P., 2004. Soil quality changes following forest clearance in Bengkulu, Sumatra, Indonesia, Biotropia. 22, 1-15.

Handayani, I. P., Coyne, M. S., Tokosh, R. S., 2009. Soil organic matter fractions and aggregate distribution in response to tall fescue stands. Int. J. Soil Sci. 5, 1-10.

Haynes, R. J., 1999. Labile organic matter fractions and aggregate stability under short-time, grass-based leys. Soil Boil. Biochem. 31, 1821-1830.

Heady, H. F., Child, R. D., 1994. Rangeland Ecology and Management. Westview Press, Boulder, USA. 519 p.

Holechek, J. L., 1989. Range Management. Prentice-Hall, Inc. USA. 501 P. 
Huang, S., Sun, Y-N., Rui, W-Y., Liu, W-R., Zhang, W-J., 2010. Long- term effect of notillage on soil organic carbon fractions in a continuous maize cropping systems of northeast China. Pedosphere. 20, 285-292.

Huxley, A., Griffiths, M., 1992. The New RHS Dictionary of Gardening. Grove's Dictionaries Publisher, UK. 3000 p.

Jackson, R. B., Banner, J. B., Jobbagy, E. G., 2002. Ecosystem carbon loss with woody plant invasion of grasslands. Nature. 418, 623-626.

Jones, C., 2006. Soil carbon and carbon credits. YLAD Living Soils Seminars. Available Online at: http://www.soilcarboncredits.blogspot.com/(accessed/pristupljeno: 10.7.2012.)

Kadović R., Belanović S., Obratov-P. D., Bjedov I., Perović V., Anđelić M., Knežević M., Ranković N., 2012. Soil organic carbon storage in mountain grasslands of the lake Plateau at Mt. Durmitor in Montenegro. BIBLID. 106, 113-128.

Laik, R., Koushlendra, K., Das, D. K., Chaturvedi, O. P., 2009. Labile soil organic matter pools in a calciorthent after 18 years of afforestation by different plantations. Appl. Soil Ecol. 42, 71-78.

Lal, R., Kimble, J. M., Follet, R. F., Stewart, B. A., 2001. Assessment methods for soil carbon advance in soil science. 1st Edn., CRC Press, Boca Raton, FL., ISBN: 9781566704618.

Leifeld, J., Kögel, K., 2005. Soil organic matter fractions as early indicators for carbon stock changes under different land-use? Geoderma. 124, 143-155.

Liao, J. D., Boutton, T. W., Jastrow, J. D., 2006. Storage and dynamics of carbon and nitrogen in soil physical fractions following woody plant invasion of grassland. Soil Biol. Biochem. 38, 3184-3196. 
Luan, J., Xiang, C. H., Liu, S. R., Luo, Z. S., Gong, Y. B., Zhu, X. L., 2010. Assessments of the impacts of Chinese fir plantation and natural regenerated forest on soil organic matter quality at Longmen mountain, Sichuan, China. Geoderma. 156, 228-236.

Marcos, D., Bongiovanni, J., Lobartini, C., 2006. Particulate organic matter, carbohydrate, humic acid contents in soil macro- and microaggregates as affected by cultivation. Geoderma. 136, 660-665.

Mcclaran M. P., Moore-kucera, J., Martens, D. A., Van haren, J., Marsh, S. E., 2008. Soil carbon and nitrogen in relation to shrub size and death in a semi-arid grassland. Geoderma. 145, 60-68.

Mendham, D. S., Heagney, E. C., Corbeels, M., OConnel, A.M., Grove, T. S., McMurtrie, R. E., 2004. Soil particulate organic matter effects on nitrogen availability after afforestation with Eucalyptus globulus. Soil Biol. Biochem. 36, 1067-1074.

Monokrousos, N., Papatheodorou, E. M., Diamantopoulos, J. D., Stamou, G. P., 2004. Temporal and spatial variability of soil chemical and biological variables in a Mediterranean shrubland. Forest Ecol. Manag. 202, 83-91.

Motamedi, J., 2009. Feasibility and executive studies on vegetation in Khanghah-e-Sorkh, Urmia University Press, Iran.

Peichl M., Leava, N. A., Kiely, G., 2012. Above-and below ground ecosystem biomass, carbon and nitrogen allocation in recently afforested grassland and adjacent intensively managed grassland. Plant Soil. 350, 281-396.

Ojima, D. S., Parton, W. J., Schimel, D. S., Scurlock, J. M. O., Kittel, T. G. F., 1993b. Modeling the effects of climatic and $\mathrm{C} 02$ changes on grassland storage of soil C. Water Air Soil Poll. 70, 643-657.

Oueslati, I., Allamano, P., Bonifacio, E. and Claps, P., 2013. Vegetation and topographic control on spatial variability of soil organic carbon. Pedosphere. 23: 48-58. 
Oksanen, L., 2001. Logic of experiments in ecology: is pseudoreplication a pseudoissue? Oikos. 94: 27-38.

Roukos, Ch. , Papanikolaou, C. , Mountousis, I ., Kandrelis, S. , Chatzitheodoridis, F., 2011. Soil property variations in relation to plant community and altitudinal zone in the rangelands of Epirus, Greece. Bulg. J. Agr. Sci. 17, 806-815.

Peichl M., Leava, N. A., Kiely, G., 2012. Above-and below ground ecosystem biomass, carbon and nitrogen allocation in recently afforested grassland and adjacent intensively managed grassland. Plant Soil. 350, 281-396.

Sequeira, C. H., Alleyy, M. M., Jones, B. P., 2011. Evaluation of potentially labile soil organic carbon and nitrogen fractionation procedures. Soil Biol. Biochem. 43, 438-444.

Six, J., Feller, C., Deneb, K., Ogle, S., Moraes, S. J., Albrecht, A., 2002. Soil organic matter, biota and aggregation in temperate and tropical soils-effects of no tillage. Agronomic. 22, 755-775.

Solomon, A. M., Prentice, I. C., Leemans, R., Cramer, W. P., 1993. The interaction of climate and land use in future terrestrial carbon storage and release. Water Air Soil Poll. 70, 595-614.

Su, Y. Z., 2007. Soil carbon and nitrogen sequestration following the conversion of cropland to alfalfa forage land in northwest China. Soil Till. Res. 92, 181-189.

Tisdall, J., 1991. Fungal Hyphae and Structural Stability of Soil. Aust. J. Soil Res. 29, 792743.

Tisdall, J. M., Oades, J. M., 1980. The management of ryegrass to stabilize aggregates of a red-brown earth, Aust. J. Soil Res. 18, 415-422.

Van Veen, J. A., Paul, E. A., 1981. Organic carbon dynamics in grassland soils. i. background information and computer simulation. Can. J. Soil Sci. 61, 185-201. 
Wang, Q., Wang, S., 2011. Response of labile soil organic matter to changes in forest vegetation in subtropical regions. Appl. Soil Ecol. 47, 210-216.

Wardle, D. A., Van der Putten, W. H., 2002. Biodiversity, ecosystem functioning and above-ground-below-ground linkages. In: Loreau, M., Naeem, S., and Inchausti, P., eds., Biodiversity and ecosystem functioning: synthesis and perspectives. Oxford University Press, pp, 155-168.

Wardle, D. A., Zackrisson, O., 2005. Effects of species and functional group loss on island ecosystem properties. Nature. 435, 806-810.

Zagal, E., Muňoz, C., Quiroz, M., Córdova, C., 2009. Sensitivity of early indicators for evaluating quality changes in soil organic matter. Geoderma. 151, 191-198. 
Figure captions

Fig. 1. Physical fractionation of soil organic matter for C (A) under two Prangos uloptera stands. POM-C is particulate organic matter C (B). Different successive letter indicate significant differences (at $\alpha=0.05$ ) between the two stands. Co-dominant species in Prangos ulopteral1 were Pterpyrum aucheri and Artemisia aucheri, and in Prangos uloptera2 were Astragalus microcephalus, Acanthophyllum microcephalum and Poa bulbosa.

Fig. 2. Physical fractionation of soil organic matter for N (A) under two Prangos uloptera stands. POM-N is particulate organic matter $\mathrm{N}(\mathrm{B})$. Different successive letter indicate significant differences (at $\alpha=0.05$ ) between the two stands. Co-dominant species in Prangos ulopteral1 were Pterpyrum aucheri and Artemisia aucheri, and in Prangos uloptera2 were Astragalus microcephalus, Acanthophyllum microcephalum and Poa bulbosa.

Fig. 3. Aggregate size distribution (macro- and micro-aggregates: A and B, respectively) under two Prangos uloptera stands. Different successive letter indicate significant differences (at $\alpha=0.05$ ) between the two stands. Co-dominant species in Prangos ulopterall were Pterpyrum aucheri and Artemisia aucheri, and in Prangos uloptera2 were Astragalus microcephalus, Acanthophyllum microcephalum and Poa bulbosa.

Fig. 4. Soil C fractions associated with aggregate size under two Prangos uloptera stands. Different successive letter indicate significant differences (at $\alpha=0.05$ ) between the two stands. Co-dominant species in Prangos ulopterall were Pterpyrum aucheri and Artemisia aucheri, and in Prangos uloptera2 were Astragalus microcephalus, Acanthophyllum microcephalum and Poa bulbosa. 

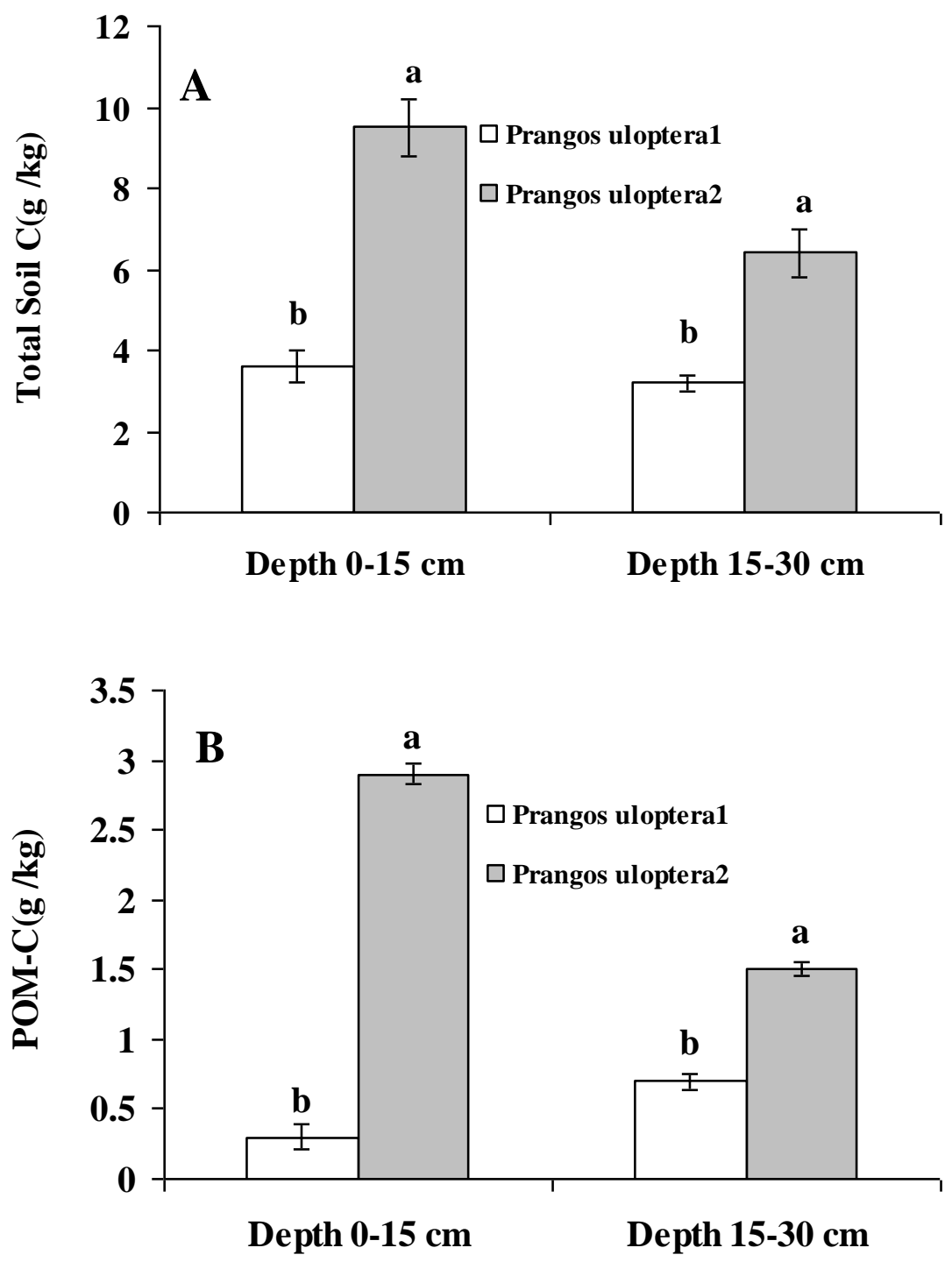

Figure 1 

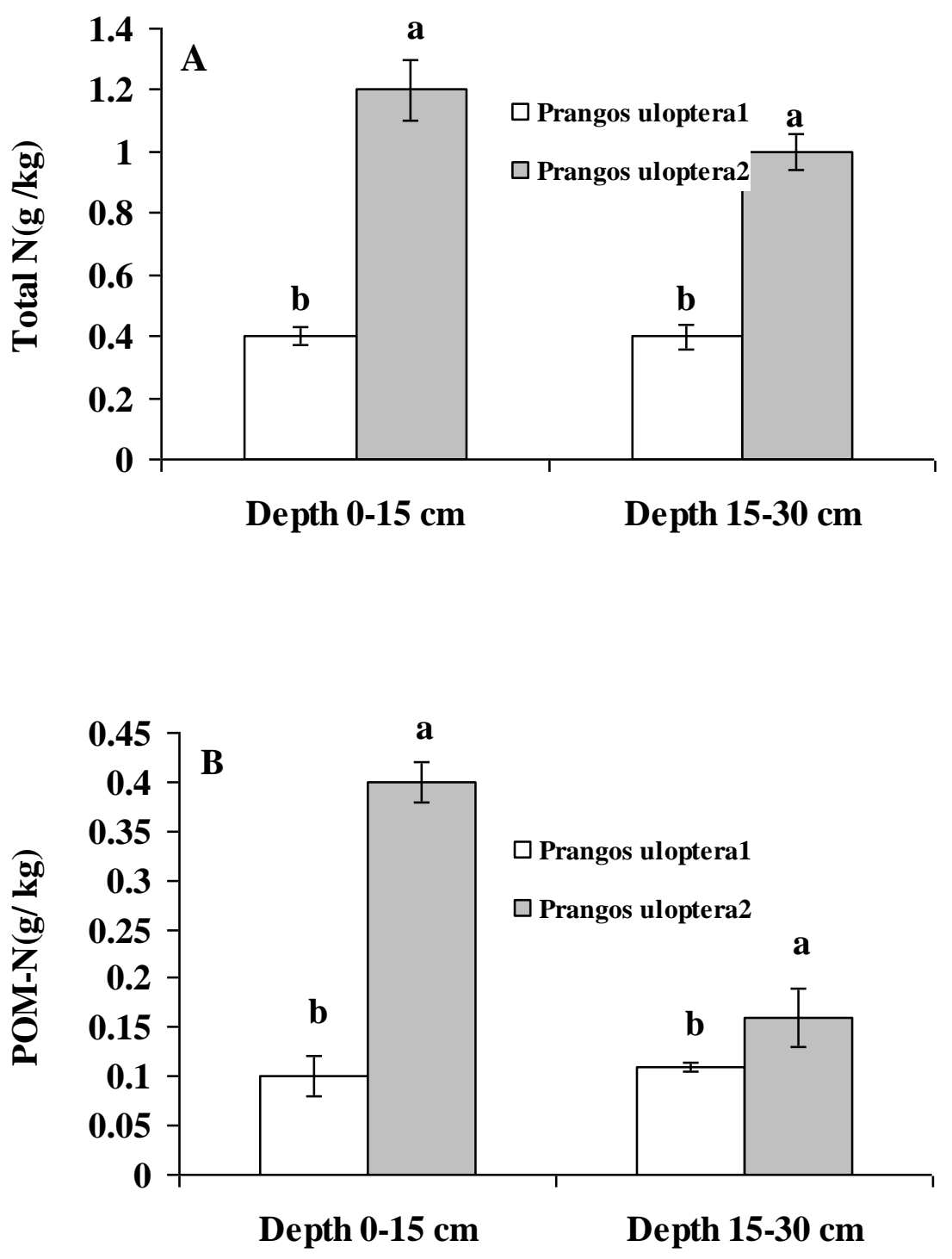

Figure 2 

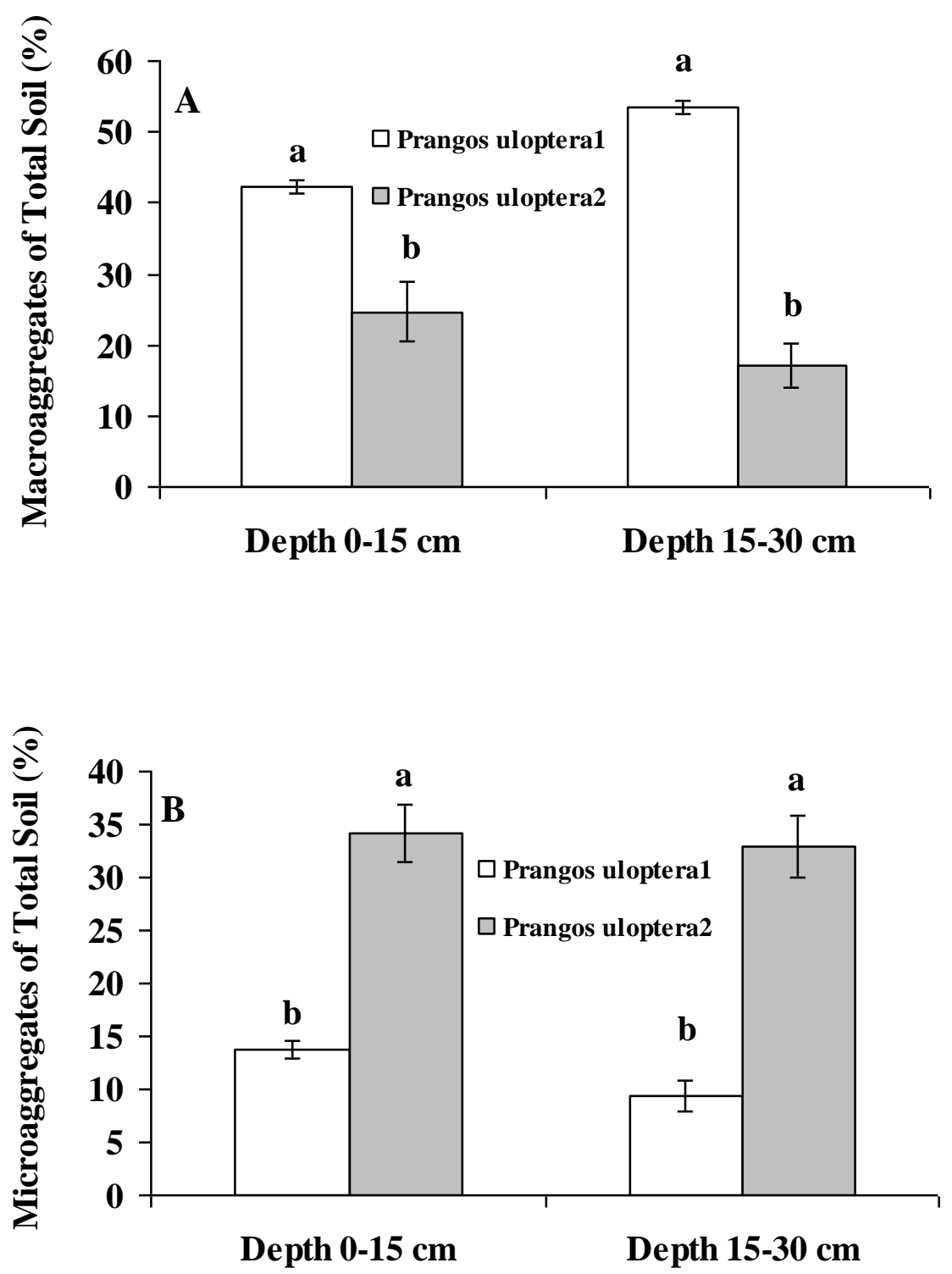

Figure 3 

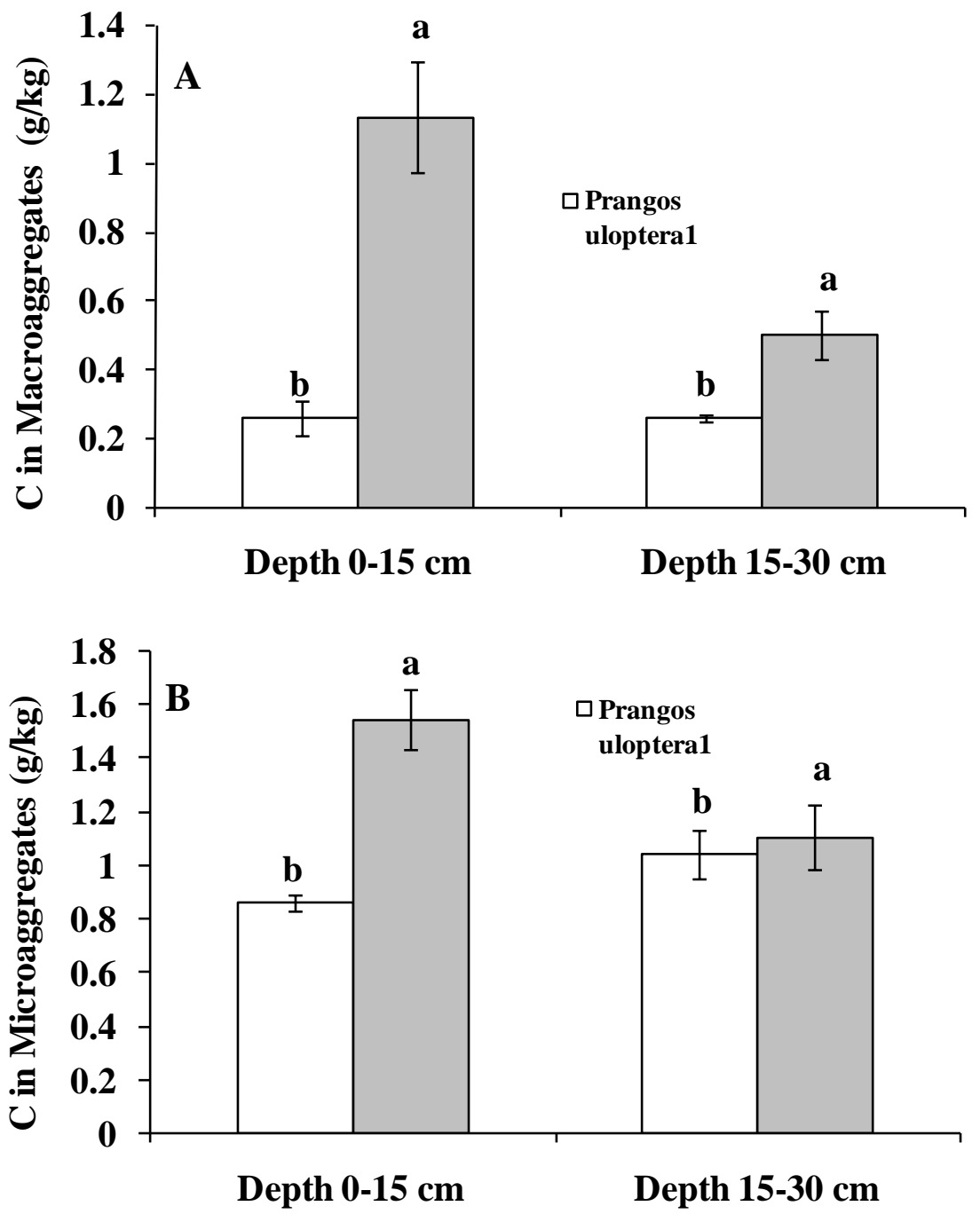

Figure 4 